УДК 94(420):327.061

DOI 10.30970/vir.2020.48.0.11037

\title{
THE GREEK-MACEDONIAN CONFLICT AND ITS IMPACT ON THE EUROPEAN INTEGRATION PROCESS IN THE BALKANS
}

\author{
Krzysztof Koźbial \\ Jagiellonian University in Kraków, \\ ul. Ingardena, 3, Kraków, Poland, 30-060, \\ e-mail:Krzysztof.kozbial@uj.edu.pl
}

The Greek-Macedonian dispute over the name of the Macedonian country had a negative impact on the stabilization in the southern Balkan region. Its duration caused a delay in talks on the accession of the state to the Union, which have not been taken up until now. Greece's behavior is difficult to describe in other words than destructive and devoid of deeper logic. The authorities in Athens denied the use of the term «Macedonia» by their northern neighbour, and then agreed to the name 'Northern Macedonia' at the turn of 2018 and 2019.

Having made this change and signing the agreement with Greece, the authorities in Skopje probably hoped to open talks on the membership in the organization in 2019. However, this has not happened yet.

Key words: North Macedonia; Greece; Greek-Macedonian conflict; European integration; Balkans; European Union.

The European Union has not set a specific date for the next enlargement since the accession of the Republic of Croatia. Its potential members should be sought in the socalled Western Balkans. However, no automatic process can be expected, the talks on this topic are pending and the final result cannot be easily predicted.

One of the prospective candidates is Macedonia ${ }^{1}$, whose talks on membership in the European Union were suspended due to the dispute with Greece. Currently, the dispute seems officially resolved. In the author's opinion, however, it may become inflamed again.

The purpose of the article is to focus on the Greek-Macedonian dispute over the name of the state. The author puts forward a hypothesis that the issue impeded considerably the process of Macedonia's accession to the EU. The article attempts to answer the following questions:

1) the reasons for the Greek-Macedonian dispute,

2) the attempts to defuse it (and their effectiveness),

\footnotetext{
${ }^{1}$ The official name of the state since February $12^{\text {th }}, 2019$ is Northern Macedonia.
} 
3) the impact of the dispute on Macedonia's membership negotiations on accession to the Union.

1. The causes of the conflict, its development and the attempts to resolve it.

The authors of the «Lexicon of Political Science» define conflict as a clash of interests between states that culminates in a diplomatic or armed confrontation [1, p. 174]. In this case the first of these instances occurred. The dispute between the two countries should definitely be considered a long-lasting one as it spanned (assuming it is over now) over 25 years. Greece kept shifting to the forum of the Union (formerly EEC), of which it has been a member since 1981, the country's conflicts with its neighbours. Thus, the authorities in Athens used their privileged position over Macedonia, resulting from the membership in the European Communities and NATO as well as from the geostrategic location in the Mediterranean Basin and in the vicinity of the Black Sea region, to disagree to its northern neighbour's accession to these organizations [25, p. 22].

- The causes of the Greek-Macedonian conflict can be summarized in five key points:

interpretation of distant events of the ancient period (the figure of Alexander the Great),

- Greece's appropriation of the name 'Macedonia',

- lack of Greece's permission to use certain symbols by Macedonia,

- Greece's refusal to recognize Slavic-speaking minorities living in the north of the country as Macedonians,

- a controversial project «Skopje 2014» implemented by the Macedonian government.

The conflict concerned, inter alia, the issue of historical policy, often shaped by the states in isolation from the realities of past events. The problem was related to the interpretation of what happened centuries ago, when Greek civilization appeared on the southern borders of the Balkan Peninsula. The sense of «Greek community» developed only during the so-called Great Colonization between the eighth and sixth centuries BC [26, p. 110-111].

In the 4th century BC Macedonia began to play an important role in this area. Demosthenes, a Greek speaker and politician, regarded Macedonians as barbarians, mainly for political reasons, considering the conquest of Greek states by Macedonians as a kind of «the end of history». In terms of language they belonged to the same language group as their Greek neighbours [26, p. 219-220]. Slavic population did not live there at the time, it appeared in the Balkans much later.

The figure of Alexander the Great, who reigned in 336-323 B.C. was the main bone of contention between Macedonia and Greece for many years. In ancient times he was an excessively idealized figure [26, p. 232]. Over the past three decades, the Macedonian state has made him even a mythical figure, naming after him the airport in Skopje and the highway leading to Greece (now the highway «Friendship»), which - as one could easily predict - was the reason for Greek protests. A similar problem 
concerned the main stadium in the capital named after Philip II of Macedonia ${ }^{2}$. The narrative aimed at recognizing Alexander as ... Macedonian, while the Greeks regarded him as ... Greek. Both interpretations should be considered absurd.

Macedonian national and independence aspirations intensified in the nineteenth century, similarly to such quests and efforts undertaken by many Slavic peoples during this period. They encountered an obstacle in the form of Serbian, Bulgarian or Greek actions.

The collapse of former Yugoslavia led to the creation of independent states, one of them was the Republic of Macedonia which proclaimed independence on September 17th, 1991. The first state that recognized independence of Macedonia was Bulgaria, but at the same time it did not recognize the existence of a separate Macedonian nation, claiming that the state is inhabited by ... Bulgarian population [17, p. 98-99].

The Bulgarian authorities' decision did not foretell an idyll for the new state. The authorities in Sofia repeatedly pointed out the aspect stressed in 1991, but they never raised it to the rank of obstacle that should impede the western neighbour's membership in the international organization. This was, on the other hand, what the authorities in Athens chose to do.

Independent Macedonia covered the territory of so-called Wardar Macedonia, extending over 25.7 thousand $\mathrm{km}^{2}$. Other parts of historic Macedonia now belong to the neighbouring countries: Greece (Aegean Macedonia), Bulgaria (Pirin Macedonia) and Albania [22, p. 51]. More than a half of the historic area of Macedonia lies within the borders of Greece. In the administrative division of this country, the term 'Macedonia' appears in the names of 3 out of 13 regions. Therefore, the Greeks claimed the exclusive right to the name Macedonia, considering it the legacy of ancient Macedonia, and assuming that its northern neighbour could not use it as the name of the state.

This was also the direction of the policy of the authorities in Athens in relation to the newly established Macedonian state. As a condition for its recognition, the Greeks demanded the change of the adopted name. Initially, this was also the policy of the then EEC expressed in the statement from the end of June 1992. After a few months, there was a change in attitude, the more so that the desire to recognize the new formation on the international stage was expressed by the USA, EEC member states and many other countries. The lack of a firm response in Brussels was also due to the fact that Greece made the signing of the Maastricht Treaty, important for the reforming Community, conditional on the acceptance of its demands towards Macedonia [20, p. 252-254]. The final solution was the admission of Macedonia to the United Nations in April 1993 under the descriptive name FYROM.

This did not mean a breakthrough in relations with Greece which in February 1994 introduced economic sanctions against Macedonia, which in turn was questioned by some European countries, the USA and the Council of Europe. As a result of the mediation on September 13th, 1995, the two countries concluded a temporary agreement on the normalization of mutual relations [10]. It confirmed the borders,

\footnotetext{
${ }^{2}$ The name has been changed to The Tose Proesky National Arena. Proeski (1981-2007) was a Macedonian singer, songwriter and actor, popular across the Balkans.
} 
agreed to respect sovereignty, renounced the use of force, and Greece pledged to recognize Macedonia as an independent state. Consequently, Greece lifted the embargo in October 1995, then Macedonia established full diplomatic relations with the US and was admitted to the Council of Europe and the OSCE. There were still ongoing talks about the name of the country.

The symbolism of the flag of independent Macedonia remained a discussion point as well. The dispute concerned the so-called Vergina Sun, which appeared on the flag of Macedonia from 1992 to 1995. The symbol was recognized by Greece as its own. In July 1995, Greece registered with the World Intellectual Property Organization an application for protection of the trademark «Vergina Sun» as a state emblem. This became possible under Article 6 of the Paris Convention for the Protection of Industrial Property [8]. This means that the symbol can only be used by the Greek state. Earlier, in 1993, the star was placed on the flags of the Greek regions with the name «Macedonia» (on a blue background), and on 100 drachmas coins introduced into circulation in the $90 \mathrm{~s}$. Therefore, the growing interest of the Greek authorities in this symbolism has become noticeable, although it was not used earlier at all. In the wake of the dispute, the Republic of Macedonia changed its flag, replacing the star with the stylized, golden, 8-pointed sun that still exists today. Eventually, the problem ceased to be conflictogenic in relationship between the two countries.

An important aspect of mutual relations is also the attitude of the Greek authorities to the Slavic population living in the north of this country. Officially, Greece does not recognize the existence of any national minority on its territory. Although it signed the Council of Europe Framework Convention for the Protection of National Minorities, it did not ratify it [5].

The Slavic population has been an important issue on several occasions in Greek internal and external policy. After World War I, as a consequence of the GreekTurkish war, the Greeks from Turkey were resettled to northern Greece. At the same time, over 50000 Macedonians emigrated from the north of Greece. After the civil war in Greece in 1949, Macedonians had to leave the area again, in the number of nearly 50000 people [22, p. 57-58]. Some of them were settled, among others countries, in Poland. The Greeks officially referred to this population as Slavophones, i.e. Greeks speaking the Slavic language. Some liberalization in relation to this population can be observed only since the mid-1980s, when the people who emigrated in the aftermath of the civil war were allowed to return, on condition they admitted having been born in Greece and assumed Greek citizenship. Currently, the use of Macedonian language in northern Greece is not a problem [21, p. 28-29]. This does not mean that the authorities in Athens officially recognise the existence of such a minority.

\section{Consequences of the dispute for European integration.}

Since the declaration of independence, the Republic of Macedonia has set itself the goal of integration with the European Union. In 2001, Macedonia was the first country in the Western Balkans to sign Stabilization and Association Agreement, which meant 
closer cooperation and preparation for the EU accession process. It came into effect tree years later [12, p. 44].

The European Union took its obligations seriously by providing financial assistance to the young state under various EU programs. In 2004, the authorities in Skopje applied to Brussels for the membership in the Union, and the efforts resulted in granting Macedonia the status of candidate country in December 2005 [17, p. 163$165 ; 15,213]$.

Only 20 months earlier such status had been granted to Croatia, a member of the EU since July 2013. These two examples clearly indicate that Macedonia could have followed the same path if it had not been for Greece's dispute over the name of the country.

If there had been a final vote on the talks with Macedonia, the authorities in Athens would certainly have exercised their right of veto. Macedonia's attempt to join NATO proves that these are not theoretical considerations. At the summit of the organization in Bucharest in 2008, the Greeks took advantage of the veto and did not agree to invite Macedonia to join the Alliance because of the name of the country [13, p. 381]. It would be similar in the case of accession to the Union. In its ruling, the International Court of Justice stated that the Greek blockade was unlawful [2]. However, this did not affect the decision of the authorities in Athens. After changing the name of the country on February 6th, 2019, Northern Macedonia signed an accession protocol to the North Atlantic Pact, thus opening its way to the Alliance [7]. In March 2020, after the ratification process by all NATO members was completed, North Macedonia acceded to NATO ${ }^{3}$.

A positive attitude to prospective membership in the organization was manifested by the Macedonian society. Opinion polls indicated support for this strategic goal by almost $90 \%$ of respondents $[15$, p. 215]. This does not mean that the country did not suffer from noticeable political and economic problems, including political and ethnic disputes with the Albanian minority, accounting for over $25 \%$ of the population, high unemployment and relatively low economic growth. In addition, the question whether Macedonia is in fact a functioning democracy could not be answered unequivocally.

In October 2009, the European Commission recommended to the EU Council opening the accession negotiations with the Balkan state, including visa liberalization [24]. Every year, Macedonia was supported in the form of pre-accession programs (currently IPA II). Every year, the state was subject to assessments by EU institutions. In the latest report from May 2019, a recommendation to start membership talks was put forward [16]. The issue of the agreement with Greece regarding the change of the name of the country was underlined, as discussed later in the article. The the biggest challenges on the road to european integration of Macedonia are: intensifying the activities related to media freedom, consistent fight against corruption organised crime and high level of unemployment and respecting the rights of ethnic minorities [12, p. 45-46].

Despite the seemingly positive attitude of Brussels, the accession talks have not been mentioned so far. In my opinion, the reasons for this state of affairs should be

\footnotetext{
${ }^{3}$ The article presents the author's state of knowledge for April $1^{\text {st }}, 2020$.
} 
sought in two issues. Firstly, there was Greece's destructive stance concerning the name of its northern neighbour. Secondly, internal problems and the lack of noticeable reforms on the part of the candidate state had an impact on the prospective talks as well. However, a similar situation in Serbia and Montenegro did not prevent the opening of accession talks with them.

In October 2019, the European Union once again decided not to start specific talks with Macedonia. At the EU Council meeting, such a request encountered opposition from France ${ }^{4}$, Denmark and the Netherlands. It is hard to disagree with the words of Commissioner for Enlargement and Policy Johannes Hahn, who said: «I am afraid we have seriously damaged our credibility in the Balkans» [6]. Undoubtedly, in this situation, it is difficult for the government in Skopje to recognize the European Union as a reliable and predictable partner.

\section{Termination of the dispute in 2018-2019.}

The dispute over the name was most likely settled in 2018-2019. This was possible mainly due to the change of the governing team in Skopje and the «new opening». Representatives of the EU institutions repeatedly emphasized that changing the name of the country was one of the key problems affecting further relations with Skopje. It was pointed out, among others things, by the heads of the EU states and governments at the European Council meeting in December 2012. The UN representative Matthew Nimetz was also engaged in the negotiations. Despite various proposals (The Upper Republic of Macedonia, The Northern Republic of Macedonia, The Wardar Republic of Macedonia) no solution was found [11, p. 37].

In 2006, Nikola Gruewski, who headed the main parliamentary group WMRODPMNE, became the longtime Prime Minister of the Macedonian government (until 2016). High expectations were put on the young, 36-year-old politician and yet they were not fulfilled. Gruewski's rule definitely kept heating up the moods both in foreign contacts (no attempt to reach agreement with Greece) as well as domestic ones (conflict with the Albanian minority). Brandishing nationalist slogans by the government officials did not contribute to stabilisation [3, p. 175-190].

Gruewski's flagship idea, controversial in terms of costs and message, was the «Skopje 2014» project. The plank of the plan: erecting monumental sculptures and buildings in order to allude the wonderful, ancient times of Macedonia, had a terrible impact on the relations with Greece. By default, the modern state was to be a continuator of those times. The alleged Macedonian heritage was exposed, although most of the public considered it to be a «cover» for the corruption of the major oligarchs of political life [19, p. 421-422]. One of the central sculptures of the project, which total costs were to exceed EUR 500 million, is a giant monument reminiscent of Alexander the Great, but officially referred to as «A Warrior on horseback» [9].

A process that could be called «archeologization» of the discourse on the national identity of Macedonians could be observed. The archaeologist Pasko Kuzman, former

${ }^{4}$ France demands, in the first place, more efficient reforms of the rule of the law implemented in the candidate counties, and the division of the negotiations into seven stages (completion of one step would allow entering the next one). 
adviser to Prime Minister Gruewski, is recognized as the project's foundation father. The goal was to preserve the name - the name of the Republic. A specific interpretation of the state's history through numerous archaeological discoveries was yet another aim. The project envisaged the construction of facilities symbolising the Macedonian past exclusively, ignoring both Albanians and Greeks [14, p. 272-288, 352-361]. The Macedonian discourse aimed at evoking traditions allegedly dating back to ancient times, with architecture creating its foundations. It offered its support for research. References to relationships with the Mediterranean civilization, as well as biblical ones were included [18, p. 183-190].

In 2016, Gruewski was forced to resign in result of the so-called eavesdropping scandal. This paved the way for - as it turned out - a slightly different policy towards the key external problems of the Republic. In May 2017, Zoran Zaew, an SDSM politician, became Prime Minister. The aim of his activities was an attempt to reach an agreement with the government in Athens regarding the name of the country. In the aftermath of the meetings of the prime ministers of both countries, a consensus was reached and the agreement in Prespa was signed (June 12th, 2018) [4], in which the government in Skopje agreed to change the name of the country to the Republic of Northern Macedonia.

To get public support for the change, on September 30th, 2018 a nationwide referendum was held. Over $94 \%$ of voters favoured the agreement with Greece, while the turnout was just under $37 \%$ (the referendum was therefore not binding). The government in Skopje could declare success, however doubtful, and continue the process of rapprochement with Greece. Prior to the referendum, Zaew's government encouraged the people to vote in favour of the agreement by arguing that this would enable negotiations with Brussels [23].

After the approval of the parliaments of Macedonia and Greece in January 2019, the agreement entered into force, thus the official name of the Macedonian state was changed in the constitution. It was an important breakthrough in mutual relations of both countries, although there were some protests on either side. Therefore monitoring the development of the international situation in this part of the Balkan peninsula seems to be of utmost importance.

In 2019, accession talks with the EU did not open, which resulted in the necessity for snap elections in Northern Macedonia. All things considered, the renegotiation of the agreement with Greece (postulated by the opposition WMRO-DPMNE), or perhaps even its termination cannot be ruled out [27, p. 1-2]. However, this is unlikely to happen because it would probably lead to a further caveat on the part of the government in Athens.

The conflict seems to be resolved, but the years to come will show whether the solution is enduring. And it applies to both sides of the conflict, because for the Greeks the agreement also raises doubts and it is a potential issue that can spark a heated discussion on both internal and external policies. 


\section{Conclusions.}

The dispute between Macedonia and Greece over the name of the country had a negative impact on the stabilization in the southern Balkan region. Its duration caused a delay in talks on the accession of the state to the Union, which have not been taken up until now. The delays might turn out difficult to be made up for, and the country might not become a member of the organization in the foreseeable future, the more so that the EU itself seems to have taken a very hesitant approach towards such a step. Greece's behavior is difficult to describe in other words than destructive and devoid of deeper logic. For years, the authorities in Athens denied the use of the term «Macedonia» by their northern neighbour, and then agreed to the name 'Northern Macedonia' at the turn of 2018 and 2019. Having made this change and signing the agreement with Greece, the authorities in Skopje probably hoped to open talks on the membership in the organization in 2019. However, this has not happened yet. The fact is that the causes for the dispute lay on both sides, for the «Skopje 2014» project alone did not contribute to the de-escalation of mutual claims.

Assuming the extrapolative function that political science should perform, the possible scenarios of events related to the discussed conflict are worth considering. The following three scenarios seem to be pertinent:

Firstly, in March 2020, Macedonia acceded to NATO, and talks about accession to the EU will commence relatively soon and will have been successfully completed by 2025 , the earliest.

Secondly, in Macedonia - due to an unsuccessful attempt to start talks on its membership in the European Union - a change of power will take place and the new government will redefine its long-term goal of accession to the Union.

Thirdly, Macedonia is a member of NATO, but due to protracted negotiations regarding the commencement of accession negotiations with the Union, this direction of the foreign policy taken by the authorities in Skopje will lose its importance. Macedonia may be interested in other development directions, e.g. rapprochement with Russia or China. Even a return to the name of the Republic of Macedonia cannot be ruled out, especially if the future parliamentary elections bring the victory of the opposition.

It is impossible to predict which of these scenarios is most likely. There is no doubt that the first one would be the most desirable in terms of stablisation in the region, keeping promises made in Brussels, and the Union's capacity for further development.

\section{REFERENCES}

1. Antoszewski Andrzej, Herbut Ryszard (ed.), Leksykon politologii, Wrocław 2003.

2. Application of the Interim Accord of 13 September 1995 (the former Yugoslav Republic of Macedonia v. Greece), https://www.icj-cij.org/en/case/142, 07.12.2019.

3. Domachowska Agata, O krok od przepaści? Rządzy koalicji VWRO-DPMNE i BDI a pogłębianie się podziałów etnicznych w Macedonii, [in:] Zenderowski Radosłąw, Cebul Krzysztof, Koziński Bartosz(ed.), Konflikty etniczne w Europie oraz w jej bezpośrednim otoczeniu po 1989 roku. Uwarunkowania, stan obecny, wyzwania dla polityki bezpieczeństwa, Warszawa 2016.

4. https://vlada.mk/sites/default/files/dokumenti/spogodba-en.pdf, 10.12.2019.

5. https://www.coe.int/de/web/conventions/full-list/-/conventions/treaty/157/signatures, 06.12.2019. 
6. https://www.euractiv.pl/section/polityka-zagraniczna-ue/news/znow-nie-udalo-sie-otworzycnegocjacji-akcesyjnych-z-albania-i-macedonia-pln/, 08.12.2019.

7. https://www.nato.int/cps/en/natohq/news_163078.htm, 10.12.2019.

8. https://www.wipo.int/cgi-6te/ifetch5?ENG+SIXTER+15-00+11521248-KEY+256+0+-1+F-ENG $+8+10+1+25+$ SEP-0/HITNUM,B+GR, 05.12.2019.

9. https://wyborcza.pl/1,75399,18217384,Projekt_Skopje_2014_Jak_ze_stolicy_Macedonii_zrobio no.html, 08.12.2019.

10. Interim Accord (with related letters and translations of the Interim Accord in the languages of the Contracting Parties). Signed at New York on 13 September 1995, https://peacemaker.un.org/sites/ peacemaker.un.org/files/MK_950913_Interim\%20Accord\%20between\%20the\%20Hellenic\%20Republic $\% 20$ and \%20the\%20FYROM.pdf, 18.02.2020.

11. Karadzoski Mladen, Adamczyk Artur, Najważniejsze problemy Macedonii w procesie integracji z Unią Europejską, „Studia Europejskie” 2015, nr 2, s. 37.

12. Koźbiat Krzysztof, The Visegrad Group Countries and the Western Balkans States. Pre-Accesion Experiences and Proposals for Macedonia, [in:] Szyszka Michał, Tomczyk Łukasz, Gulevska Valentina Petrovski Dobri (ed.), Modern social and educational challenges and phenomena. Polish and Macedonian perspective, Cracow-Bitola 2015.

13. Koźbiał Krzysztof, Unia Europejska jako czynnik stabilizacyjny na Bałkanach. Stan obecny i wyzwania na przyszłość. [in:] Knopek Jacek (ed.), Unia Europejska jako współczesny aktor stosunków międzynarodowych. Toruń 2009.

14. Majewski Piotr, (Re)konstrukcje narodu. Odwieczna Macedonia powstaje w XXI wieku, Gdańsk 2013.

15. Mirchev Dimitar, Macedonia and its policy of accession towards the European Union, «CROSSROADS - The Macedonian Foreign Policy Journal» 2007, issue 2.

16. North Macedonia 2019 Report, Commission staff working document, Brussels 2019, SWD (2019) 213 final, p. 3, https://ec.europa.eu/neighbourhood-enlargement/sites/near/files/20190529-northmacedonia-report.pdf, 07.12.2019.

17. Olszewski Pawet, Macedonia. Historia i współczesność, Radom 2010.

18. Rekśś Magdalena, Mity narodowe i ich rola w kreowaniu polityki na przykładzie państw byłej Jugosławii, Łódź 2013.

19. Rekść Magdalena, Wyobrażenia zbiorowe społeczeństw byłej Jugosławii w XXI wieku. Perspektywa politologiczna, Łódź 2019.

20. Sokołowska Patrycja, Polityka zagraniczna i bezpieczeństwa RFN wobec państw obszaru byłej Jugosławii w latach 1990-2005, Torun 2010.

21. Stawowy-Kawka Irena, Ludność Macedonii - zmiany struktury narodowościowej w XX wieku, «Dzieje Najnowsze»1998, No 30/2.

22. Stawowy-Kawka Irena, Narodowe i państwowe aspiracje Macedończyków, [in:] Batowski Henryk, Machnik Jan (ed.), Prace Komisji Środkowoeuropejskiej PAU, vol. I, Kraków 1993.

23. Szpala Marta, Macedonia Północna: decyzja o przyspieszonych wyborach parlamentarnych, https://www.osw.waw.pl/pl/publikacje/analizy/2019-10-23/macedonia-polnocna-decyzja-o-przyspieszo nych-wyborach-parlamentarnych, 10.12.2019.

24. The Former Yugoslav Republic of Macedonia, 2011 Progress Report, Commission staff working paper, Brussels 2011, SEC (2011) 1203 final, p. 3, https://ec.europa.eu/neighbourhoodenlargement/sites/near/files/pdf/key_documents/2011/package/mk_rapport_2011_en.pdf, 07.12.2019.

25. Wiśniewska Paula, Stolarek Kamil, Europejska polityka Grecji, Opole 2016. (ETE Working Paper 2016, vol. 2, No 4).

26. Wolski Józef, Historia powszechna. Starożytność, Warszawa 1992.

27. Żornaczuk Tomasz, Wyhamowanie rozszerzenia Unii Europejskiej na Bałkanach, «Biuletyn $\mathrm{PISM»nr} 163$ (1911) z 21 listopada 2019 r. 


\section{ГРЕКО-МАКЕДОНСЬКИЙ КОНФЛІКТ ТА ЙОГО ВПЛИВ НА ПРОЦЕС} СВРОПЕЙСЬКОЇ ІНТЕГРАЦІЇ НА БАЛКАНАХ

\section{Кшиштоф Козбял}

Ягеллонський університет, вул. Інгардена, 3, м. Краків, Республіка Польща, 30-060, e-mail: krzysztof.kozbial@uj.edu.pl

Греко-македонська суперечка «про назву держави» тривала від моменту проголошення незалежності Македонії. В 1995 р. Македонія була змушена змінити свої національні символи, зображені на прапорі. Через напруження у відносинах Греція заблокувала вступ колишньої югославської республіки до НАТО.

Обнадійливим стало порозуміння між державами 2018-2019 pp., що виявилося у згоді Македонії змінити офіційну назву на «Республіка Північна Македонія». Це порозуміння $\epsilon$ важливим для процесу європейської інтеграції на Балканах. Воно забезпечує підстави для продовження діалогу Брюсселя і Скоп'є, котрий може привести до інтеграції цієї держави зі структурами Свросоюзу.

Ключові слова: Македонія; Греція; Суперечка щодо назви Македонії; європейська інтеграція; Балканський півострів. 